\title{
White Fiber
}

National Cancer Institute

\section{Source}

National Cancer Institute. White Fiber. NCI Thesaurus. Code C33891.

A type of striated skeletal muscle fiber that contracts quickly and contains small amounts of mitochondria, myoglobin and sarcoplasm. 